УДК 338.43

\title{
КОМПОНЕНТНИЙ АНАЛІЗ СТРАТЕГІЧНОГО ПЛАНУВАННЯ РОЗВИТКУ РЕГІОНУ
}

\section{COMPONENT ANALYSIS OF STRATEGIC REGIONAL DEVELOPMENT PLANNING}

\author{
Кіш Галина Вікторівна \\ кандидат економічних наук, доцент, \\ ДВНЗ «Ужгородський національний університет» \\ ORCID: https://orcid.org/0000-0002-6201-9589 \\ Світлинець Ольга Володимирівна \\ кандидат фрілософських наук, доцент, \\ ДВНЗ «Ужгородський національний університет» \\ ORCID: https://orcid.org/0000-0002-0007-8751
}

\author{
Kish Galyna, Svitlynets Olha \\ Uzhhorod National University
}

\begin{abstract}
Стаття присвячена дослідженню проблем стратегічного планування на регіональному рівні. Визначено, що фрундаментом ефективної стратегії регіонального розвитку є всебічний аналіз, який може включати наступні складові: соціально-економічний аналіз, аналіз внутрішніх сильних і слабких сторін і розпізнавання зовнішніх можливостей і загроз, визначення конкурентних переваг, фрормування концепції розвитку та визначення стратегічних цілей. Встановлено, що наступним етапом після фрормування фрундаментального стратегічного базису є розробка операційної частини стратегії, яка складається 3 компонентних планів розвитку: економічного, соціального та екологічного. Підкреслено значимість взаємозв'язку даних компонент, на базі якого можливе фрормування синергетичних проектів регіонального розвитку.
\end{abstract}

Ключові слова: стратегія, стратегічне планування, регіон, регіональний розвиток, розвиток регіону.

Статья посвящена исследованию проблем стратегического планирования на региональном уровне. Определено, что фундаментом эфффективной стратегии регионального развития является всесторонний анализ, который может включать в себя следующие составляющие: социально-экономический анализ, анализ внутренних сильных и слабых сторон и распознавание внешних возможностей и угроз, определение конкурентных преимуществ, формирование концепции развития и определение стратегических целей. Установлено, что следующим этапом после фрормирования фрундаментального стратегического базиса явлется разработка операционной части стратегии, которая состоит из компонентных планов развития: экономического, социального и экологического. Подчеркнута значимость взаимосвязи данных компонент, на базе которого возможно формирование синергетических проектов регионального развития.

Ключевые слова: стратегия, стратегическое планирование, регион, региональное развитие, развитие региона.

The article is devoted to the study of strategic planning problems at the regional level. The main objectives of the article are the analysis of the existing component stages of strategic planning, highlighting the role of the strategic approach to regional development planning, the disclosure of key components of strategic planning of regional development. Globalization processes of the world economy contribute to increasing the role of competition between states and their territories. Modern strategic management is the impetus for the formation and implementation of the region's development strategy based on continuous monitoring and analysis of environmental change. It is used to support the region and providing it with support at the state level. The search for new regional ways development and increasing the competitiveness is becoming more urgent in a crisis period. It is determined that the foundation of an effective regional development strategy is a comprehensive analysis, which may include the following components: socio-economic analysis, analysis of internal strengths and weaknesses and identification of external opportunities and threats, identification of competitive advantages, development concept and strategic goals. The next stage after the formation of the fundamental strategic basis is the development of the operational part of the strategy, which consists of component development plans: economic, social and environmental. The importance of the inter- 
connection of these components, based on which it is possible to form synergetic regional development projects, is emphasized. Thus, harmonious development of Ukraine as a sovereign state with a competitive economy, is impossible without the effective development of each of its regions, which have their own economic potential and their own basis for economic growth. A rational tool for regional development management is strategic planning, which makes it possible to implement synergetic projects of all three components: economic, social and environmental.

Keywords: strategy, strategic planning, strategic management, region, regional development, regional.

Постановка проблеми. Останнім часом питання, пов'язані зі стратегічним плануванням розвитку регіону, все частіше з'являються на сторінках економічних видань. Це свідчить про їх важливість в теорії та практиці управління національним господарством країни і її регіонів. У сучасних умовах господарювання стратегічне планування набуває особливого значення для забезпечення ефрективного управління розвитком регіону.

Аналіз останніх досліджень і публікацій. Питанням стратегічного планування регіонального розвитку присвятили свої праці такі науковці, як: Нєма О., Козак І., Качний О. С., Звєряков М. І., Кухарська Н. О., Клевцевич Н. А., Шараг О. С., Пастух К., Шинкарьов А., Проданик В. та інші. Проте невизначеність деяких питань, пов'язаних з організацією цього процесу, зумовлює потребу в подальших розробках у цьому напрямку.

Формулювання цілей статті. Основними цілями статті $€$ аналіз існуючих компонентних етапів стратегічного планування, виділення ролі стратегічного підходу до планування регіонального розвитку, розкриття ключових компонентів стратегічного планування регіонального розвитку.

Виклад основного матеріалу дослідження. Процес стратегічного планування починається із формування стратегічного базису, який представляє собою довгострокову стратегічну частину. Саме вона виступає фрундаментом ефрективної стратегії регіонального розвитку і включає наступні складові:

1. Соціально-економічний, який аналіз охоплює всі важливі аспекти життєдіяльності і розвитку цільового регіону. Цей аналіз також створює потужну основу для своєчасного виявлення бажаних і небажаних змін в регіоні, а також основу для прийняття обґрунтованих рішень щодо регіонального розвитку. Хороший соціально-економічний аналіз регіону попереджає: він показує, від чого слід відмовлятися (де витрати перевищують вигоди), а також - куди потрібно спрямовувати ресурси, де $\epsilon$ потенціал для розвитку. Підготовка якісного соціально-економічного аналізу $є$ дуже важливим елементом для всієї роботи над стратегією регіонального розвитку, адже саме такий аналіз дає змогу визначити сильні та слабкі сторони регіону, оцінити можливі сценарії розвитку та визначити внутрішні ресурси і конкурентні переваги регіону перед іншими регіонами.

2. SWOT-аналіз являє собою ефективний метод ідентифрікації внутрішніх сильних і слабких сторін і розпізнавання зовнішніх можливостей і загроз. SWOT-аналіз показує, яким чином краще застосувати власні сили і зменшити внутрішні слабкості, оптимально використовуючи зовнішні можливості та усуваючи загрози. Таким чином, SWOT-аналіз зазвичай використовується для виявлення найбільш важливих внутрішніх і зовнішніх фракторів, що мають значення для розвитку. SWOT-аналіз являє собою синтез ситуаційного аналізу, який вказує на основні внутрішні фрактори (сильні і слабкі сторони), та зовнішні фрактори (можливості і загрози), важливі для розвитку. Філософрію SWOT можна резюмувати наступним чином: спиратися на сильні сторони, усувати слабкі сторони та використовувати можливості.

3. Визначення і відбір конкурентних переваг. Регіональний розвиток стає інструментом для досягнення глобальної конкурентоспроможності на регіональному рівні через процес, за допомогою якого регіони управляють постійними конкурентними трансорормаціями, аби стати більш комфортними для життя і кращими для ведення бізнесу. Конкурентні переваги є оракторами конкурентоспроможності, які являють собою вимоги, щоб зробити один регіон більш привабливим, ніж інші. Поняття конкурентоспроможності було запозичено 3 підприємницького сектору, і зазвичай, застосовується для розвитку територій.

4. Визначення концепції (бачення) розвитку є поворотним пунктом в процесі розробки стратегії. 3 цього моменту припиняється аналіз ситуації і починається фрормулювання бажаних досягнень в регіоні зі стратегічної точки зору, заснованої на висновках. Хороше бачення має відображати взаємно пов'язані внутрішній і зовнішній виміри. У той час, як внутрішній вимір показує спільну думку зацікавлених сторін регіону щодо типу громади, яку вони хочуть побудувати протягом визначеного стратегічного періоду, зовнішній вимір 
показує конкурентні позиції, які регіон намагається завоювати у відповідному середовищі. Обидва виміри конкурентної позиції повинні бути засновані на унікальних конкурентних перевагах, які регіон створив або може створити відповідно до власних сприятливих, але реалістичних зовнішніх можливостей.

5. Визначення стратегічних цілей, які народжуються на основі концепції (бачення) розвитку та визначених стратегічних напрямів, представляють першу трансорормацію і конкретизацію бачення і акцентів. Вони встановлюють основні напрямки для досягнення бачення і ототожнюють кінцеві результати, які повинні бути досягнуті до кінця стратегічного періоду. Заключна частина стратегічної платфрорми включає в себе визначення стратегічних цілей і контроль щодо їх узгодження по горизонталі і вертикалі.

Наступним етапом після формування фрундаментального стратегічного базису є розробка операційної частини стратегії, яка складається 3 компонентних (економічний, соціальний та екологічний) планів розвитку. Три компоненти економічний розвиток, соціальний розвиток та захист навколишнього середовища - $є$ основою регіонального розвитку.

Основними цінностями для економічного розвитку мають стати проблемні питання і фрактори розташування для цільових галузей і компаній. В цілому ссрерою економічних інтересів $є$ підвищення економічної спроможності регіону, а також спрямування, сприяння та прискорення реструктуризації економіки регіону. Метою компоненту економічного розвитку $є$ поліпшення умов для економічного зростання та зайнятості, підвищення еконо-

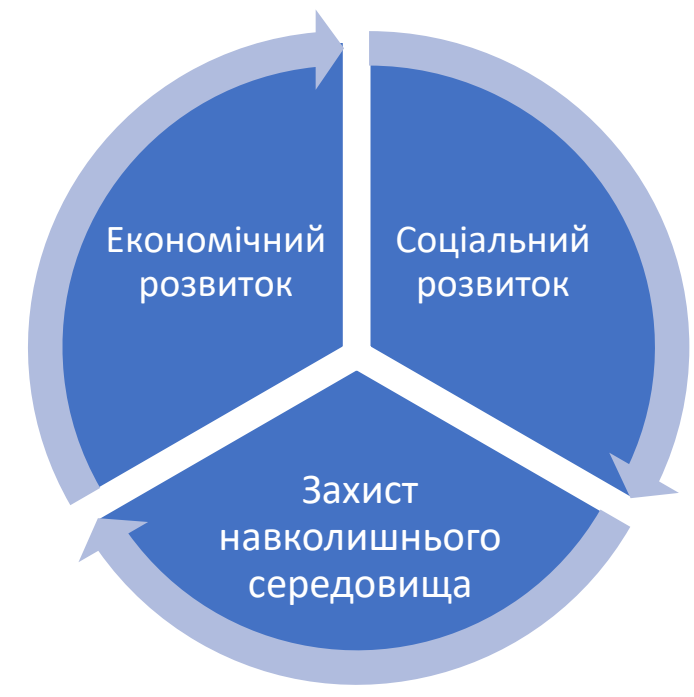

Рис. 1. Складові компоненти стратегії регіонального розвитку мічних можливостей та конкурентоспроможності, забезпечення економічного майбутнього і якості життя для всіх жителів регіону. Ефективне планування та реалізація економічного розвитку потребують активної участі і взаємодії між партнерами з державних, приватних та неурядових організацій.

Щодо соціального розвитку, то базовою цінністю $є$ наявність якісних послуг для різних цільових груп. Важливим $€$ створення «здорової» громади, зміцнення соціальної інтеграції і соціального капіталу, покращення публічних послуг тощо. План соціального розвитку включає необхідні зміни в регіоні, які дозволять покращити досягнення економічних, соціальних, культурних, спортивних та інших прав і потреб громадян. Успішна реалізація плану соціального розвитку забезпечує більш рівні можливості та покращує соціальну інтеграцію. При цьому, підтримку соціального сектору слід розглядати як інвестиції в соціальне забезпечення громадян, надаючи їм можливість брати участь у суспільному та економічному житті, а не просто як інструмент для виплат фрінансової та іншої допомоги вразливим категоріям населення з причин суспільної необхідності.

Екологічна складова зосереджує свою увагу на пріоритетах і зонах ризику, та відповідальне управління ресурсами та довкіллям. Якісний план захисту (і покращення) навколишнього середовища повинен гарантувати відповідальне і стале управління навколишнім середовищем та природними ресурсами, які одночасно відповідають потребам нинішнього і майбутніх поколінь. Цей план повинен бути узгоджений 3 економічним розвитком і компонентом соціального розвитку. Відповідна інфрормація, необхідна для підготовки плану захисту навколишнього середовища, дістається через соціально-економічний аналіз. Соціально-економічний аналіз повинен також містити перелік екологічних проблем, у тому числі основних забруднюючих джерел і матеріалів, а також їх потенційного впливу на здоров'я людини, навколишнє середовище та якість життя. Компонентне фокусування повинно визначити центр уваги в сорері захисту навколишнього середовища та плану поліпшення в майбутньому [2].

Хоча деякі стратегії розвитку та відповідні підходи до їх підготовки не передбачають однозначної розробки компонентних планів, вони досі чітко містять цілі та механізми реалізації для підтримки соціально-економічного розвитку, одночасно опікуючись питаннями 
просторового розвитку, охорони навколишнього середовища та збереження природних ресурсів. Підготовка плану для кожного компоненту потребує проведення відповідних фокусгруп за участю членів команди розробників у відповідності до їх знань та інтересів. Кожна фокус-група повинна включати компетентних та зацікавлених представників від державного, приватного та громадського сектору, і також може бути посилена лідерами громадської думки і експертами у відповідних сорерах.

До процесу розробки кожного компонента варто залучати також представників групи зацікавлених сторін. Для економічного розвитку - представників бізнес-сектору, для соціального розвитку - представників уразливих груп, для плану захисту навколишнього середовища - фрахівців-екологів.

Незалежно від того, наскільки добре визначені цілі розвитку, їх досягнення вимагає повсякденної роботи 3 виконання 3 точним розподілом ресурсів і відповідальності. Після завершення компонентних планів (економічного розвитку, соціального розвитку та захисту навколишнього середовища) необхідно розробити чітку основу для їх реалізації. Рамки реалізації повинні надати ясну картину механізмів реалізації. Мінімальна структура рамок реалізації: план реалізації (матриця проекту, зі списком проектів і заходів у відповідності до трьох компонентів), фрінансовий план, план моніторингу і оцінки, план зміцнення спроможності.

Визначивши значимість кожної 3 трьох складових, необхідно розуміти, що найкращий синергетичний есрект для розвитку регіону можуть дати комплексні проекти, що охоплюють всі три стратегічні компоненти. Для прикладу це можуть бути:

1. "Рівномірний та інтегрований міський розвиток". Йдеться про заходи щодо зміцнення ролі міст та центрів зростання, наприклад удосконалення соціальної інфрраструктури та житла, модернізації міського транспорту, підтримки економічної активності у міських районах, покращення екології та навколишнього природного середовища міських (та приміських) зон розвитку.

2. "Регіональна та локальна доступність". Мета - забезпечити кращі зв'язки між міськими зонами та віддаленими від них районами через дорожнє та транспортне будівництво; активізувати будівництво інорраструктури енергетичних зв'язків; удосконалити інфрраструктуру мереж комунікаційних та інорормаційних технологій.
3. Розвиток туризму. Пріоритетами цього напряму $€$ розвиток та модернізація туристичної інфрраструктури (насамперед упорядкування культурних та історичних пам'яток, розвиток готельного сектору); покращення туристичного обслуговування в межах всієї країни; зміцнення партнерства між суб'єктами туристичної сорери та інших сорер. Розвиток туризму створює сприятливі умови для розвитку малого бізнесу (особливо у сорері послуг), сприяє зростанню самозайнятості населення “зелений туризм", зменшує безробіття.

4. Місцевий розвиток та співпраця. Цей пріоритет фрормування «точок зростання» стосується периферійних місцевих громад, які потребують припливу інвестицій для покращення умов життя та місцевому рівні (за винятком найбільш густонаселених міських районів). Найбільшого значення набувають інвестиції у промислову, освітню інфрраструктуру та інфраструктуру охорони здоров'я. На практиці цей процес відбувається за рахунок активізації місцевої ініціативи, об'єднання фрінансових та матеріальних ресурсів сусідніх місцевих громад [10]. Розвиток гендерного компоненту, що передбачає активне залучення жінок до життя громад і прийняття рішень, впровадження ґендерно-бюджетного орієнтування при напрацюванні регіональних стратегій розвитку, реалізація найкращих регіональних практик, створення ґендерної платформи.

У період виходу з кризи та посткризовий період для системи державного управління регіональним розвитком в Україні пріоритетного значення набувають стимулювання інноваційних напрямків розвитку регіону з урахуванням наявного на місцевому рівні ресурсного потенціалу; орієнтація на комплексний розвиток внутрішнього (локального регіонального та загальнонаціонального) ринку, стимулювання міжрегіональної кооперації та інтеграції; пошук «точок зростання» на регіональному рівні, задіяння дієвих інструментів їх розкриття та стимулювання саморозвитку регіональних соціально-економічних систем [11].

Висновки. Гармонійний розвиток України як суверенної держави, яка йде до побудови конкурентоспроможної економіки, неможливий без ефективного розвитку кожного її регіону, які мають свій економічний потенціал і власну основу для економічного зростання. Раціональним інструментарієм управління регіонального розвитку є стратегічне планування, що дає можливість здійснювати синергетичні проекти всіх трьох компонентів: економічного, соціального та екологічного. 


\section{СПИСОК ВИКОРИСТАНИХ ДЖЕРЕЛ:}

1. Постанова № 695 Про затвердження Державної стратегії регіонального розвитку на 2021-2027 роки від 05.08.2020 p. URL: https://zakon.rada.gov.ua/laws/show/695-2020-\%D0\%BF\#Text

2. Методологія планування регіонального розвитку в Україні. URL: https://cg.gov.ua/web_docs/1/2014/11/ docs/Methodology_of_RD_planning.pdf

3. Нєма О., Козак І. Планування регіонального розвитку в контексті децентралізації. Ефеективність державного управління. 2017. Вип. 2(51). Ч. 2. С. 222-228.

4. Качний О.С. Стратегічне планування як один із найсучасніших методів державного управління регіональним соціально-економічним розвитком. Державне управління: удосконалення та розвиток. 2018. № 2. URL: http://www.dy.nayka.com.ua/pdf/2_2018/23.pdf

5. Кухарська Н. Закордонний досвід стратегічного планування регіонального розвитку. Економічний аналіз. 2020. Том 30. № 1. Частина 1. С. 118-125.

6. Звєряков М.І., Кухарська Н.О., Клевцевич Н.А., Шараг О.С. Стратегування регіонального розвитку: теорія, методологія, концепція : монограсрія. Одеський національний економічний університет МОН України. Одеса : Атлант ВОI COІУ, 2019. 241 с.

7. Кіш Г.В. Стратегічне планування як інструмент управління національної економіки. Науковий вісник Ужгородського університету. Серія «Економіка». 2015. Випуск 1(45). Т. 3. С. 73-77.

8. Пастух К. Стратегічне планування розвитку територіальних громад. Науковий вісник : Державне управління. 2021. № 1(7).

9. Шинкарьов А., Проданик В. Організаційно-правові засади стратегічного планування у сфері розвитку регіонів України. Наукові записки Інституту законодавства Верховної Ради України. 2021. № 1. С. 115-121.

10.Регіональна політика Європейського Союзу : підручник / [за ред. Віктора Чужикова]. Київ : KHЕУ, 2016. 495 с.

11. Бугас Н.В. Особливості регіонального розвитку як об'єкта управлінського впливу держави. Ефективна економіка. 2017. № 2.

\section{REFERENCES:}

1. Postanova № 695 Pro zatverdzhennya Derzhavnoyi stratehiyi rehional'noho rozvytku na 2021-2027 roky vid 05.08.2020 r. [Resolution № 695 On approval of the State Strategy for Regional Development for 2021-2027 dated 05.08.2020]. Available at: https://zakon.rada.gov.ua/laws/show/695-2020-\%D0\%BF\#Text

2. Metodolohiya planuvannya rehional'noho rozvytku v Ukrayini [Methodology of regional development planning in Ukraine]. Available at: https://cg.gov.ua/web_docs/1/2014/11/docs/Methodology_of_RD_planning.pdf

3. Nyema O., Kozak I. (2017) Planuvannya rehional'noho rozvytku v konteksti detsentralizatsiyi [Regional development planning in the context of decentralization]. Efektyvnist' derzhavnoho upravlinnya, vol. 2(51), p. 2, pp. 222-228.

4. Kachnyy O.S. (2018) Stratehichne planuvannya yak odyn iz naysuchasnishykh metodiv derzhavnoho upravlinnya rehional'nym sotsial'no-ekonomichnym rozvytkom [Strategic planning as one of the most modern methods of public administration of regional socio-economic development]. Derzhavne upravlinnya: udoskonalennya ta rozvytok, no. 2. Available at: http://www.dy.nayka.com.ua/pdf/2_2018/23.pdf

5. Kukhars'ka N. (2020) Zakordonnyy dosvid stratehichnoho planuvannya rehional'noho rozvytku [Foreign experience of strategic planning of regional development]. Ekonomichnyy analiz, vol. 30, no. 1, part 1, pp. 118-125.

6. Zvyeryakov M.I., Kukhars'ka N.O., Klevtsevych N.A., Sharah O.S. (2019) Stratehuvannya rehional'noho rozvytku: teoriya, metodolohiya, kontseptsiya [Regional development strategy: theory, methodology, concept]: monohrafiya [a monograph]. Odessa National Economic University of the Ministry of Education and Science of Ukraine. Odessa: Atlant WOI SOIU, 241 p. (in Ukrainian)

7. Kish G.V. (2015) Stratehichne planuvannya yak instrument upravlinnya natsional'noyi ekonomiky [Strategic planning as a tool for managing the national economy]. Scientific Bulletin of Uzhhorod University. "Economics" series, vol. 1(45), tom 3, pp. 73-77.

8. Pastukh K. (2021) Stratehichne planuvannya rozvytku terytorial'nykh hromad [Strategic planning of territorial communities' development]. Scientific Bulletin: Public Administration, no. 1(7).

9. Shynkarov A., Prodanyk V. (2021) Organizacijno-pravovi zasadi strategichnogo planuvanja u sferi rozvitku regioniv Ukraini [Organizational and legal basis of strategic planning in the field of development of Ukrainian regions]. Scientific Papers of the Legislation Institute of the Verkhovna Rada of Ukraine, no. 1, pp. 115-121.

10. Rehional'na polityka Yevropeys'koho Soyuzu: pidruchnyk (2016) [Regional policy of the European Union] / [za red. Viktora Chuzhykova]. Kyiv: KNEU, 495 p.

11. Buhas N.V. (2017) Osoblyvosti rehional'noho rozvytku yak obyekta upravlins'koho vplyvu derzhavy [Features of regional development as an object of managerial influence of the state]. Efficient economy, no. 2. 